\title{
Influence of Management on Quality Assurance in National Teacher's Colleges
}

\author{
Josephine Lubwama, David Onen and Edris Serugo Kasenene \\ College of Education and External Studies \\ Makerere University, Uganda
}

\begin{abstract}
This study investigated the influence of management on quality assurance in National Teachers Colleges (NTCs) in Uganda. The study was prompted by the persistent complaints from key stakeholders about the deteriorating quality of teacher trainees from the NTCs. The study used the descriptive cross-sectional sample survey research design where both qualitative and quantitative approaches to data collection and analysis were used to gain an in-depth understanding of the issues that were investigated. Data were collected from 79 lecturers, three principals, six deputy principals, three academic registrars, and two officials from the Uganda's Ministry of Education and Sports. Study respondents were selected through purposive and convenience sampling techniques. Data were analysed through the use of appropriate descriptive and inferential statistics as well as a content analysis technique. Study results revealed that planning $(p=.001<.05)$, controlling $(p=.047<.05)$, and directing $(p=.000<.05)$ have statistically significant influence on quality assurance; meanwhile, organizing $(p=.148>.05)$ has a statistically weak influence on quality assurance in NTCs. The researchers thus concluded that management significantly influences the assurance of quality in NTCs in Uganda, other factors notwithstanding. It was therefore recommended that periodic audits and reviews need to be undertaken by managers of NTCs in order to detect any anomalies regarding quality in their institutions. Besides, the principles of total quality management need to be incorporated in the management of quality at NTCs so as to engage all relevant stakeholders such as students and employees in managing quality at the institutions. Finally, the managers of NTCs are recommended to benchmark and adapt best practices of assuring quality from other institutions of higher education.
\end{abstract}

Keywords: management; quality assurance; planning; organising; controlling.

\section{Introduction}

World over, the importance of quality education is no longer debatable - more so - the quality of teacher education. This is because as world leaders and educationalists often say, there is "no educational system [in the world that] is 
better than [the quality of] its teachers" (UNESCO, 2017, para. 1). As a result, the issue of assuring quality in teacher education is a matter of grave concern not only to government and policy-makers but scholars as well. Unfortunately, the process of assuring quality in teacher education is no easy feat - not even for developed nations. The case of National Teacher's Colleges (NTCs) in Uganda is no exception. In this paper, the researchers present the results of a study that delved into the influence of management on quality assurance in NTCs in Uganda. The investigation was prompted by the persistent complaints from key stakeholders about the deteriorating quality of teacher trainees from these NTCs.

In Uganda, NTCs have a history that dates far back to 1948 when the colonial government then established the first teacher training college at Nyakasura. According to Adupa and Mulindwa (1998), the teacher college of the time admitted students who were holders of ordinary school certificate $\left(\mathrm{O}^{\prime}\right.$ level $)$ and up-graders who held Grade II teacher certificate. The two authors also contend that for a long time, the teacher training colleges in Uganda continued to produce teachers of relatively very good quality if compared with the ones of today. However, the political and economic events of the 1970s and 80s caused significant damage to the country's education system leading to a decline in the overall quality of education - including teacher education.

Several scholars have already delved into the potential causes of the declining quality of teacher education elsewhere as well as in Uganda. Many such scholars attribute the decline in the quality of teacher education to the weaknesses in the quality assurance systems put in place to guarantee quality in the teacher training institutions. Yet with effective management, it can be hypothesized that quality assurance should be guaranteed. It is this kind of theorization that prompted these researchers to look into how the management in NTCs in Uganda is influencing the assurance of quality in these institutions; thus, the genesis of this investigation.

Theoretically, this study was modeled on the theory of total quality management (TQM) advanced in the 1950s by scholars such as Edwards Deming, Joseph M. Juran, and Armand V. Feigenbaum (Smith, 2011). The theory states that an organization should involve all its stakeholders especially staff in the day-to-day management of quality if it is to guarantee the quality of its products and services. In fact, according to Singh (2011), TQM aims to do the right things, right the first time, every time. However, for TQM to be successful, quality management should become the culture of the organisation and the organisation should commit itself to applying the principles of TQM which according to Deming (1986), include: commitment by management and employees, meeting client requirements, improving teams has some systems to facilitate improvement, line management ownership, employee involvement and empowerment, recognition and celebration, focus on processes or improvement plans and specific incorporation in strategic planning (Hashmi, 2017). In this study, the theory of TQM was opted for because although originally the theory was applied to manufacturing operations, and for several years only used in that area, TQM is now a recognized management tool applicable even in the provision of services in public sector organizations including educational 
institutions. The researchers believed that if the NTCs embraced the principles of TQM in their operations, then quality assurance would be guaranteed.

In the study, there were two main concepts: management and quality assurance. According to Rodrigues (2001), management is the process of planning, organizing coordinating, directing, and controlling of resources to achieve organization goals. But, Mullins (2010) defines management as the process of getting things done by working both with and through people operating in organized groups. In this study, the definition of management was borrowed from the work of Rodrigues. As a result, management was looked at as the process by which administrators of NTCs in Uganda, plan, direct, control and organize the quality assurance function of their colleges.

The second key concept in this study was quality assurance (QA). According to Harman and Meek (2000), QA refers to "the systematic management and assessment procedures adopted by a higher education institution or system to monitor performance and to ensure achievement of quality outputs or improved quality" (p.iv). Harman again defined QA in a more or less similar manner in his publication of 2000 titled 'Quality Assurance in Higher Education'. Harvey and Green (1993) and Harvey (2005) on the other hand defined QA as the means by which managers satisfy themselves that mechanisms put in place are working to maintain standards and satisfy all stakeholders that the product meets the prescribed standards. It is this second definition that was adopted for the purpose of this study. As a result, QA was looked at in terms of the systems put in place by the managers of the NTCs to guarantee the production of quality teacher trainees.

Contextually, this study was conducted in three out of the five public NTCs in Uganda. This was instigated by the fact that all recent reviews of the NTCs by the Ministry of Education and Sports have been revealing a decline in the quality of teacher trainees from these institutions in spite of the substantial investments that the Ministry has made over the years (Ministry of Education and Sports, 2015). Besides, the organs such as the governing councils and staff committees that were set up to ensure quality in the institutions were reportedly found to be rather inert; and according to some stakeholders, these developments were already beginning to hurt the quality of the products of these institutions since some employers were already complaining about the quality of the teachers trained by the colleges. The researchers believed that if the current scenario persisted, then the graduates of these institutions would eventually be rendered unemployable and this would lead to the wastage of resources used to train them. The researchers specifically wondered if management was playing its due role in guaranteeing quality in the NTCs; thus, the genesis of the study.

Study Objectives. This study was intended to establish the influence of management on quality assurance in the NTCs. Specifically, it was meant to find out the influence of: (i) planning; (ii)organizing; (iii)controlling; and (iv)directing on quality assurance in the colleges. 


\section{Methodology}

The study employed a descriptive cross-sectional sample survey research design where both qualitative and quantitative data were collected. The use of both qualitative and quantitative data collection approaches was aimed at enabling the researchers to gain an in-depth understanding of the issues under investigation. The data were collected from 79 lecturers, three principals, six deputy principals, three academic registrars, and two officials from the Uganda's Ministry of Education and Sports using questionnaires (for lecturers only) and interview guide (for the other categories of respondents. This study design was opted for because it enabled the researchers to collect data at one point in time in order to understand the issues that were under investigation without returning to the field to collect data several times. This implies that the research design helped the researchers to cut down on costs and to save time that would be spent in conducting the entire study. In addition, by using the survey design, it was intended to allow the researchers to generalize the findings obtained from the sampled population to the entire target population of the study. The researchers used convenience and purposive sampling techniques to choose the different groups of study subjects. Convenience sampling techniques were used to identify the lecturers while the rest of the members of the sampled population was identified through purposive sampling techniques. These sampling techniques helped in identifying those who were privy to the kind of information that the researchers were interested in. It, therefore, helped to cut down on costs and time that would be wasted trying to gather data from irrelevant subjects. The data were analysed with the use of appropriate statistical techniques and well as content analysis method of qualitative data analysis.

\section{Results}

The study aimed to determine the influence of management - precisely: planning, organising, controlling, and directing on quality assurance in NTCs. In this section, the researchers present the results of the study. The first result to be presented in Table 1 is on respondents' background information.

Table 1: Demographic characteristics of the respondents

\begin{tabular}{|c|c|c|c|}
\hline Variable & Attributes & Frequency & Percent \\
\hline \multirow[t]{3}{*}{ Sex of respondent } & Male & 54 & 68.4 \\
\hline & Female & 25 & 31.6 \\
\hline & Total & 79 & 100.0 \\
\hline \multirow[t]{4}{*}{ Respondent's roles } & Subject Head & 23 & 29.1 \\
\hline & Departmental Head & 16 & 20.3 \\
\hline & Ordinary Lecturer & 40 & 50.6 \\
\hline & Total & 79 & 100.0 \\
\hline \multirow{3}{*}{$\begin{array}{l}\text { Respondent's } \\
\text { highest academic } \\
\text { qualification }\end{array}$} & Bachelor's Degree & 44 & 55.7 \\
\hline & Master's Degree & 35 & 44.3 \\
\hline & Total & 79 & 100.0 \\
\hline \multirow{5}{*}{$\begin{array}{l}\text { Respondent's years } \\
\text { of service at College }\end{array}$} & Less than a year & 6 & 7.6 \\
\hline & Between 1 and 5 years & 16 & 20.3 \\
\hline & $6-10$ years & 22 & 27.8 \\
\hline & Above 10 years & 35 & 44.3 \\
\hline & Total & 79 & 100.0 \\
\hline
\end{tabular}


The results in Table 1 show that more male lecturers $(68.4 \%)$ participated in the study than their female counter-parts (32.6\%). This may suggest that there are more male lecturers employed in the NTCs than their female counter-parts. Secondly, the results also show that the majority of the lecturers who participated in this study were ordinary lecturers; that is, individuals with no specific assigned administrative or managerial role(s). This means that the views and opinions they gave regarding how quality is assured in their colleges may not be biased since they hold no administrative posts in the institutions. This may help to raise the validity and reliability of the study findings. Thirdly, the results in Table 1 also indicate that the majority of the lecturers (55.7\%) that participated in the study possess bachelor degrees. This implies that the bulk of the study participants were knowledgeable about the issues under investigation. Finally, the results in Table 1 also reveal that the majority of the study participants $(72.1 \%)$ have worked in their respective colleges for periods extending beyond five years. This implies that they are knowledgeable about the management and the assurance of quality in their institutions. This should also help to raise the validity and reliability of the study results.

\section{Descriptive statistics on independent and dependent variables}

The researchers sought the views of the respondents on each of the study variables that were investigated. The respondents were given statements with which they were requested to agree or disagree in order to determine what they think or feel about the management of their colleges and how it influences quality assurance. The researchers used a three-point Likert scale ranging from disagree (D) coded as 1 to agree (A) - coded as 3. The results depicting the respondents' views on planning, organising, controlling, and directing are hereby presented in tables 2 to 5 .

Table 2: Respondents' rating on items related to planning

\begin{tabular}{|c|c|c|c|c|c|}
\hline Questionnaire Item & $\mathrm{D}$ & UD & $\mathrm{A}$ & Mean & SD \\
\hline $\begin{array}{l}\text { College plans and services are } \\
\text { aligned to institutional mission }\end{array}$ & $\begin{array}{l}12 \\
(15.7 \%)\end{array}$ & $\begin{array}{l}7 \\
(8.9 \%)\end{array}$ & $\begin{array}{l}60 \\
(76.0 \%)\end{array}$ & 2.12 & 1.084 \\
\hline $\begin{array}{l}\text { College is focused on ensuring } \\
\text { quality of its products }\end{array}$ & $\begin{array}{l}10 \\
(12.6 \%)\end{array}$ & $\begin{array}{l}7 \\
(8.9 \%)\end{array}$ & $\begin{array}{l}62 \\
(78.5 \%)\end{array}$ & 2.33 & .0981 \\
\hline $\begin{array}{l}\text { Administrators undertake } \\
\text { College's SWOT analysis }\end{array}$ & $\begin{array}{l}6 \\
(7.6 \%)\end{array}$ & $\begin{array}{l}10 \\
(12.7 \%)\end{array}$ & $\begin{array}{l}63 \\
(79.8)\end{array}$ & 2.40 & .934 \\
\hline $\begin{array}{l}\text { College has institutional plan } \\
\text { in line with mission }\end{array}$ & $\begin{array}{l}74 \\
(94.7 \%)\end{array}$ & $\begin{array}{l}0 \\
(0 \%)\end{array}$ & $\begin{array}{l}6 \\
(6.3 \%)\end{array}$ & 1.95 & .766 \\
\hline $\begin{array}{l}\text { All staff are engaged in } \\
\text { preparing institutional plans. }\end{array}$ & $\begin{array}{l}4 \\
(5.1 \%)\end{array}$ & $\begin{array}{l}12 \\
(15.2 \%)\end{array}$ & $\begin{array}{l}63 \\
(79.8 \%)\end{array}$ & 2.42 & .854 \\
\hline $\begin{array}{l}\text { The College has planned/set } \\
\text { communication procedures }\end{array}$ & $\begin{array}{l}74 \\
(93.7 \%)\end{array}$ & $\begin{array}{l}0 \\
(0.0)\end{array}$ & $\begin{array}{l}2.5 \\
(6.3 \%)\end{array}$ & 2.54 & .945 \\
\hline
\end{tabular}




\begin{tabular}{llllll}
\hline $\begin{array}{l}\text { College has plan for } \\
\text { replenishing its staffing levels }\end{array}$ & $\begin{array}{l}6 \\
(7.6)\end{array}$ & $\begin{array}{l}5 \\
(6.3 \%)\end{array}$ & $\begin{array}{l}68 \\
(86.1 \%)\end{array}$ & 2.40 & .768 \\
\hline $\begin{array}{l}\text { College has CPD programs for } \\
\text { its staff }\end{array}$ & $\begin{array}{l}60 \\
(75.9 \%)\end{array}$ & $\begin{array}{l}13 \\
(16.5 \%)\end{array}$ & $\begin{array}{l}6 \\
(7.6 \%)\end{array}$ & & \\
\hline $\begin{array}{l}\text { College has plans for its } \\
\text { quality M \& E }\end{array}$ & 43.94 & .965 \\
\hline $\begin{array}{l}\text { College supports staff in } \\
\text { ensuring quality outputs }\end{array}$ & $(54.5 \%)$ & 13 & 23 & 2.61 & 1.126 \\
& $(45.6 \%)$ & $(8.9 \%)$ & $(45.6 \%)$ & & \\
\hline
\end{tabular}

The results in Table 2 indicate that most of the respondents (60 or 76\%) agreed that their colleges' plans and services were aligned to institutional vision, mission, and goals with a mean response of 2.12. However, a total of $10(13 \%)$ respondents strongly disagreed that their colleges' plans were aligned with institutional mission and goals. This implies that some lecturers were not aware or involved in the planning of activities in their institutions.

The results also revealed that $79.8 \%$ of the respondents agreed that the academic staff of the colleges is engaged in preparing operational plans for their respective institutions, and this was reflected in the average mean response of 2.42 . However, a total of $19 \%$ disagreed that they were not involved in planning for their institutions. This meant that college administrators hardly involve a section of their staff in planning for the institutions. This may make it difficult for all staff members to get involved in assuring quality.

With regard to the procedures of communication used in NTCs, results in Table 2 indicate that most of the respondents (58 or 73\%) disagreed with the fact that their institutions have well-planned communication procedures (mean response of 2.54). This could mean that there are coordination difficulties when it comes to implementation of institutional plans as well as in ensuring quality. Some of the respondents (31 or $39 \%$ ) strongly disagreed that there were plans to provide staff with continuous professional development opportunities. Yet, $17 \%$ of the respondents were undecided about the availability of continuous professional development opportunities in their institutions. This might imply that the plans to provide staff with continuous professional development are lacking or not exposed to all the academic staff.

During the interviews, several interviewees expressed different opinions regarding the planning function in the NTCs. The academic registrars observed that while the mission, goals, objectives, and rules of the institutions were wellwritten and exposed through brochures, notice-boards and other media, the staff hardly takes the trouble to read and internalize them. In fact, one Academic Registrar revealed during the interview that:

It is difficult to understand academicians. Once they are given their appointment letters, they will never bother to look at anything else. I should tell you that all the appointment letters and other documents of 
the College have the College's mission and vision clearly written on them.

This could partly explain why some staff members were indicating that their colleges lack institutional plans, mission, and vision.

The second dimension of management that was investigated in the study was organizing. In Table 3, the researchers present the views of respondents with regard to how the organising function in their colleges was handled.

Table 3: Respondents rating on organizing

\begin{tabular}{|c|c|c|c|c|c|}
\hline Questionnaire Item & $\mathrm{D}$ & UD & $\mathrm{A}$ & Mean & SD \\
\hline $\begin{array}{l}\text { In our College, academic heads } \\
\text { coordinated academic decisions }\end{array}$ & $\begin{array}{l}15 \\
(19.0 \%)\end{array}$ & $\begin{array}{l}6 \\
(7.6 \%)\end{array}$ & $\begin{array}{l}58 \\
(73.5 \%)\end{array}$ & 2.14 & 1.237 \\
\hline $\begin{array}{l}\text { In our College, lecturer-student } \\
\text { ratio is satisfactory }\end{array}$ & $\begin{array}{l}47 \\
(2 \%)\end{array}$ & $\begin{array}{l}10 \\
(12.7 \%)\end{array}$ & $\begin{array}{l}22 \\
(27.8 \%)\end{array}$ & 1.15 & 1.159 \\
\hline $\begin{array}{l}\text { In our College, support } \\
\text { supervision is well offered }\end{array}$ & $\begin{array}{l}11 \\
(13.9 \%)\end{array}$ & $\begin{array}{l}18 \\
(22.8 \%)\end{array}$ & $\begin{array}{l}50 \\
(63.3 \%)\end{array}$ & 2.22 & 1.033 \\
\hline $\begin{array}{l}\text { In our College, new staff are } \\
\text { given good induction }\end{array}$ & $\begin{array}{l}66 \\
(83.5 \%)\end{array}$ & $\begin{array}{l}1 \\
(1.3 \%)\end{array}$ & $\begin{array}{l}12 \\
(15.2 \%)\end{array}$ & 2.11 & 1.152 \\
\hline $\begin{array}{l}\text { In our College, good staff } \\
\text { appraisal is done }\end{array}$ & $\begin{array}{l}52 \\
(65.8 \%)\end{array}$ & $\begin{array}{l}4 \\
(5.1 \%)\end{array}$ & $\begin{array}{l}23 \\
(29.0 \%)\end{array}$ & 2.52 & 1.309 \\
\hline $\begin{array}{l}\text { In our College, there are } \\
\text { departmental budgets }\end{array}$ & $\begin{array}{l}22 \\
(27.8 \%)\end{array}$ & $\begin{array}{l}2 \\
(2.5 \%)\end{array}$ & $\begin{array}{l}55 \\
(60.7 \%)\end{array}$ & 2.14 & 1.217 \\
\hline $\begin{array}{l}\text { Our college has adequate physical } \\
\text { infrastructure }\end{array}$ & $\begin{array}{l}3 \\
(3.8 \%)\end{array}$ & $\begin{array}{l}7 \\
(8.9 \%)\end{array}$ & $\begin{array}{l}69 \\
(87.4 \%)\end{array}$ & 2.41 & .845 \\
\hline $\begin{array}{l}\text { Our college has adequate non- } \\
\text { phyiscal facilities }\end{array}$ & $\begin{array}{l}14 \\
(17.7 \%)\end{array}$ & $\begin{array}{l}19 \\
(24.1 \%)\end{array}$ & $\begin{array}{l}45 \\
(57.0 \%)\end{array}$ & 2.87 & 1.221 \\
\hline $\begin{array}{l}\text { Our College has adequate } \\
\text { computers and its accessories }\end{array}$ & $\begin{array}{l}48 \\
(60.7 \%)\end{array}$ & $\begin{array}{l}7 \\
(8.9 \%)\end{array}$ & $\begin{array}{l}24 \\
(30.4 \%)\end{array}$ & 2.48 & 1.413 \\
\hline $\begin{array}{l}\text { In our College there is an effective } \\
M \text { \& E system }\end{array}$ & $\begin{array}{l}42 \\
(53.2 \%)\end{array}$ & $\begin{array}{l}5 \\
(6.3 \%)\end{array}$ & $\begin{array}{l}32 \\
(40.5 \%)\end{array}$ & 2.89 & 1.132 \\
\hline $\begin{array}{l}\text { In our College, ICT system is fully } \\
\text { utilised }\end{array}$ & $\begin{array}{l}73 \\
(92.4 \%)\end{array}$ & $\begin{array}{l}4 \\
(5.1 \%)\end{array}$ & $\begin{array}{l}2 \\
(2.6 \%)\end{array}$ & 1.65 & .752 \\
\hline $\begin{array}{l}\text { The College has sufficient library } \\
\text { and its facilities }\end{array}$ & $\begin{array}{l}19 \\
(24.0 \%)\end{array}$ & $\begin{array}{l}14 \\
(17.7 \%)\end{array}$ & $\begin{array}{l}46 \\
(58.3 \%)\end{array}$ & 2.08 & 1.269 \\
\hline
\end{tabular}

The results in Table 3 show that $53 \%$ of the lecturers agreed that in their institutions, academic heads coordinate academic decisions as compared to $18 \%$ 
of them who disagreed. This implies that the academic heads are to a large extent, responsible for the decisions made regarding academic affairs - including the issue of quality assurance. The results also reveal that a total of $62 \%$ of the respondents disagreed about lecturers being inducted in their roles, with a mean response rate of 2.11 . However, $13.9 \%$ of the respondents agreed that lecturers were inducted in their roles. This could mean that there is the induction of lecturers in the colleges, not to all recruited lecturers. That explains why some lecturers were not aware of the induction programmes in their institutions. Moreover, it is important to induct all lecturers after being recruited because they get to learn the culture of the institution and how quality is assured in it.

Further, when respondents were asked if there is a staff appraisal system in the college and whether timely feedback was given to them, some of the respondents $(43 \%)$ disagreed with this statement, with a mean response rate of 2.52. This could have meant that some lecturers were not aware of the appraisal system in place. Moreover, a yearly appraisal is mandatory.

The results in Table 3 also show that some of the respondents disagreed (33\%) that lecture halls and computer labs were adequate and useful in teaching, with an observed mean response rate of 2.48 . However, $19 \%$ of the respondents agreed with the statement that lecture halls and computer labs were adequate and useful in teaching. This meant that the staff members were unsatisfied with the state of facilities in the institutions and regarding the availability of resources.

During the interviews, several interviewees expressed different opinions regarding the organizing function in the NTCs. In fact, many principals and their deputies confirmed that the lecturer-student ratio in their institutions was not yet satisfactory. One principal observed that:

In this era of universal secondary education where enrolment has been increasing year after year without additional recruitment of staff, there is no way how the lecturer to student ratio can be satisfactory. Most often, we find that our lecture halls are crowded beyond capacity. This is not healthy for effective teaching and learning.

Therefore, this scenario may account for the deteriorating quality of teaching and learning in the NTCs. In fact, the results from the interviews corroborated the quantitative data presented.

Thirdly, the researchers investigated how the controlling function of management was handled in the NTCs and whether it was influencing quality assurance in the colleges. The descriptive results are presented in Table 4: 
Table 4: Respondents' rating on Controlling

\begin{tabular}{|c|c|c|c|c|c|}
\hline Questionnaire Item & $\mathrm{D}$ & UD & $\mathrm{A}$ & Mean & SD \\
\hline $\begin{array}{l}\text { College has established } \\
\text { performance standards }\end{array}$ & $\begin{array}{l}7 \\
(8.8 \%)\end{array}$ & $\begin{array}{l}3 \\
3.8 \%)\end{array}$ & $\begin{array}{l}69 \\
(87.3 \%)\end{array}$ & 2.28 & .868 \\
\hline $\begin{array}{l}\text { Our output is compared } \\
\text { against set goals }\end{array}$ & $\begin{array}{l}64 \\
(81.0 \%)\end{array}$ & $\begin{array}{l}1 \\
(1.3 \%)\end{array}$ & $\begin{array}{l}14 \\
(17.7 \%)\end{array}$ & 2.22 & .915 \\
\hline $\begin{array}{l}\text { Our performance is } \\
\text { regularly appraised }\end{array}$ & $\begin{array}{l}6 \\
(7.6 \%) \\
\end{array}$ & $\begin{array}{l}18 \\
(22.8 \%) \\
\end{array}$ & $\begin{array}{l}55 \\
(69.6 \%) \\
\end{array}$ & 2.14 & .813 \\
\hline $\begin{array}{l}\text { We are given periodic } \\
\text { support supervision }\end{array}$ & $\begin{array}{l}61 \\
(77.2 \%) \\
\end{array}$ & $\begin{array}{l}7 \\
(8.9 \%) \\
\end{array}$ & $\begin{array}{l}11 \\
(14.0 \%)\end{array}$ & 1.97 & 1.062 \\
\hline $\begin{array}{l}\text { At College, we do self- } \\
\text { evaluation }\end{array}$ & $\begin{array}{l}14 \\
(17.7 \%) \\
\end{array}$ & $\begin{array}{l}0 \\
(0.0 \%)\end{array}$ & $\begin{array}{l}65 \\
(82.3 \%) \\
\end{array}$ & 2.29 & .930 \\
\hline $\begin{array}{l}\text { We receive sufficient } \\
\text { communication }\end{array}$ & $\begin{array}{l}21 \\
(26.6 \%)\end{array}$ & $\begin{array}{l}4 \\
(5.1 \%)\end{array}$ & $\begin{array}{l}54 \\
(68.4 \%)\end{array}$ & 2.08 & 1.023 \\
\hline $\begin{array}{l}\text { At College, there is } \\
\text { assured funding source }\end{array}$ & $\begin{array}{l}57 \\
(72.1 \%) \\
\end{array}$ & $\begin{array}{l}0 \\
(0.0 \%) \\
\end{array}$ & $\begin{array}{l}22 \\
(27.9 \%) \\
\end{array}$ & 2.53 & 1.338 \\
\hline $\begin{array}{l}\text { At College, funding } \\
\text { goals are clear }\end{array}$ & $\begin{array}{l}57 \\
(72.2 \%) \\
\end{array}$ & $\begin{array}{l}4 \\
(5.1 \%) \\
\end{array}$ & $\begin{array}{l}18 \\
(22.8 \%) \\
\end{array}$ & 2.24 & 1.283 \\
\hline $\begin{array}{l}\text { Our College has an } \\
\text { effective financial system }\end{array}$ & $\begin{array}{l}55 \\
(69.6 \%) \\
\end{array}$ & $\begin{array}{l}15 \\
(19 \%)\end{array}$ & $\begin{array}{l}9 \\
(11.4 \%)\end{array}$ & 2.23 & 1.154 \\
\hline $\begin{array}{l}\text { NCHE regularly } \\
\text { monitors our College }\end{array}$ & $\begin{array}{l}69 \\
(87.4 \%)\end{array}$ & $\begin{array}{l}0 \\
(0.0 \%)\end{array}$ & $\begin{array}{l}10 \\
(12.7 \%)\end{array}$ & 1.87 & .939 \\
\hline $\begin{array}{l}\text { Local managers also } \\
\text { regularly conduct } \mathrm{M} \& \mathrm{E}\end{array}$ & $\begin{array}{l}64 \\
(71.0 \%)\end{array}$ & $\begin{array}{l}5 \\
(6.3 \%)\end{array}$ & $\begin{array}{l}10 \\
(12.7 \%)\end{array}$ & 1.65 & 1.063 \\
\hline
\end{tabular}

The results in Table 4 reveal that most of the respondents (80\%) agreed that there were established performance standards in the colleges with a mean response rate of 2.28 . However, $6.3 \%$ of the respondents disagreed with this statement. This implied that there was a small percentage of lecturers in the NTCs who were not following the performance standards or were not aware of their existence. On whether actual performance is compared against set standards, most of the respondents (66\%) disagreed with this statement with a mean response rate of 2.22; however, $18 \%$ of the respondents agreed to the statement. This implied that actual performance was not compared against the set standards thereby inhibiting the assurance of quality in the institutions.

The results in Table 4 also revealed that some of the respondents (41\%) disagreed that there were periodic support supervision and evaluation of staff performance with a mean response rate of 1.97 . However, $13 \%$ of the lecturers who participated in the study agreed that the colleges carried out periodic support supervision. This implied that periodic support supervision and evaluation of staff is irregularly carried out.

The results in Table 4 also showed that a large proportion of respondents (67\%) disagreed with the statement that the National Council for Higher Education (NCHE) regularly monitors and evaluates colleges' activities, with a mean 
response rate of 1.87 . This meant that the NCHE does not regularly monitor and evaluate colleges' activities.

During interviews, several interviewees expressed diverse opinions about the issue of controlling as a management function in the colleges. One Deputy Principal observed that:

As a college, we have tried to put in place several control measures. These include things timetables, budgets, duty Rota, room allocation committee, academic committee, and so on and so forth in order to help us enhance quality in the institution. However, these measures sometimes are not effective in guaranteeing quality due to several factors. For example, some lecturers do not adhere to the timetables, thereby causing confusion in the institution. This does not give a good example to the teacher trainees.

With regards to academic standards, one interviewee observed that:

... everybody in academia circle here knows their performance standards. They are actually clearly spelt out in one's appointment letter, and we just keep reminding ourselves in various fora. But all I can say is that the staff here is performing averagely well, generally.

While the interviewee indicated that the staff members of this NTC were doing well, from what was observed, the researchers believed that there were still gaps in performance that could be filled. In fact, this idea was supported by one Academic Registrar who said that:

It is the duty of all lecturers to do a self-check on how they are performing, and although this is not mandatory, we encourage them to do it. They get feedback from the students in as far as their performance is concerned. There are reports of improved performance based on feedback from self-evaluation.

This confirmed that while some managers were satisfied with the performance of their staff, others were not - implying that there was still room for improvement in the performance of the lecturers towards ensuring quality in the NTCs.

Finally, the researchers examined how the directing function of management was carried out at the colleges and whether it was adequately influencing quality assurance. The descriptive results are hereby presented in Table 5 below.

Table 5: Respondents Rating on items related to Directing

\begin{tabular}{|c|c|c|c|c|c|}
\hline Item & $\mathrm{D}$ & UD & $\mathrm{A}$ & $\begin{array}{l}\text { Mea } \\
\mathrm{n}\end{array}$ & SD. \\
\hline $\begin{array}{l}\text { The administration inspires } \\
\text { actions to be taken by others }\end{array}$ & $\begin{array}{l}12 \\
(15.2 \%)\end{array}$ & $\begin{array}{l}8 \\
(10.1)\end{array}$ & $\begin{array}{l}59 \\
(74.6 \%\end{array}$ & 2.25 & 1.255 \\
\hline Understanding the workers' & $\begin{array}{l}50 \\
(63.3 \%)\end{array}$ & $\begin{array}{l}5 \\
(6.3 \%)\end{array}$ & $\begin{array}{l}24 \\
(30.4 \%\end{array}$ & 2.56 & 1.337 \\
\hline $\begin{array}{l}\text { The administrators give timely } \\
\text { feedback }\end{array}$ & $\begin{array}{l}60 \\
(76.0 \%)\end{array}$ & $\begin{array}{l}4 \\
(5.1 \%)\end{array}$ & $\begin{array}{l}15 \\
(19 \%)\end{array}$ & 1.90 & 1.161 \\
\hline
\end{tabular}




\begin{tabular}{|c|c|c|c|c|c|}
\hline $\begin{array}{l}\text { Communication channels } \\
\text { assembly }\end{array}$ & $\begin{array}{l}5 \\
(6.3 \%)\end{array}$ & $\begin{array}{l}0 \\
(0.0 \%)\end{array}$ & $\begin{array}{l}74 \\
(93.7 \%\end{array}$ & 2.43 & .904 \\
\hline $\begin{array}{l}\text { Students are involved in } \\
\text { academic affairs }\end{array}$ & $\begin{array}{l}0 \\
(0.0 \%) \\
\end{array}$ & $\begin{array}{l}0 \\
(0.0 \%) \\
\end{array}$ & $\begin{array}{l}79 \\
100.0 \% \\
\end{array}$ & 2.59 & .468 \\
\hline $\begin{array}{l}\text { The library equipped and } \\
\text { accessible }\end{array}$ & $\begin{array}{l}24 \\
(30.4 \%)\end{array}$ & $\begin{array}{l}1 \\
(1.3 \%)\end{array}$ & $\begin{array}{l}54 \\
(68.4 \%\end{array}$ & 2.00 & 1.43 \\
\hline Multimedia instruction material & $\begin{array}{l}66 \\
(83.5 \%) \\
\end{array}$ & $\begin{array}{l}3 \\
(3.8 \%)\end{array}$ & $\begin{array}{l}10 \\
(12.6 \%)\end{array}$ & 1.77 & 1.085 \\
\hline
\end{tabular}

The results in Table 5 indicate that majority of the respondents $(47 \%)$ agreed that the administration inspires them to take relevant quality assurance actions with a mean rate of 2.25. This meant that the administration motivates others to take actions that guarantee quality in the colleges. However, some of the respondents (13\%) disagreed with that statement, implying that there might have been some lecturers who did not appreciate the administrators' efforts to inspire them.

In Table 5, the results also show that the majority of the respondents (41\%) disagreed that the college's leadership understand the workers' personalities, values, attitudes, and emotions. This implies that managers of the colleges do not fully address personal issues of the lecturers and understand them. About the statement that managers give timely feedback, the majority of the respondents $(53.2 \%)$ disagreed with a mean response rate of 1.90 . A total of 30 percent of the respondents agreed with the statement that managers give timely feedback. This could mean that many of the managers in the NTCs hardly provide feedback to the staff about quality assurance related issues.

During interviews, different respondents expressed diverse opinions about how directing was carried out in the colleges and how this was contributing to the assurance of quality in the institutions. One Principal observed that:

As a Principal, I always try my best to lead my staff in a professional manner. I always encourage them to work hard, remain focused and ensure that they perform quality work. I have seen many of my staff inspired and motivated to do quality work. I believe that my other colleagues are as well doing the same.

Another Principal also said something similar to the first principal cited above; she reiterated that:

It is not easy today to manage public servants. Many of them have a negative attitude towards work and their superiors. This makes it difficult for institutional leaders like me to guide what the staff should do or not do. In some cases, we clash with some staff members especially on the issues of professionalism and presentation of shoddy work.

This means that while the quantitative results indicate that many colleges' leaders inspire and motivate their staff, the leaders themselves express difficulty in directing the staff as well as the institution.

On the other hand, the researchers also sought the opinions of the respondents about quality assurance at their colleges. Using 15 questions, respondents were made to rate the status of quality assurance basing on a 3-point Likert scale 
ranging from $1=$ Disagree (D), $2=$ Undecided (UD), and $3=$ Agree (A). The summary of the descriptive results is presented here in Table 6.

Table 6: Descriptive Statistics on Respondents' Rating on Quality Assurance

\begin{tabular}{|c|c|c|c|c|c|}
\hline Item & $\mathrm{D}$ & UD & $\mathbf{A}$ & Mean & SD \\
\hline $\begin{array}{l}\text { There is regular academic staff } \\
\text { evaluation }\end{array}$ & $\begin{array}{l}30 \\
(38.0 \%)\end{array}$ & $\begin{array}{l}6 \\
(7.6 \%)\end{array}$ & $\begin{array}{l}43 \\
(54.4 \%)\end{array}$ & 2.94 & 1.497 \\
\hline $\begin{array}{l}\text { Internal examinations given to } \\
\text { students }\end{array}$ & $\begin{array}{l}35 \\
(44.3 \%)\end{array}$ & $\begin{array}{l}11 \\
(13.9 \%)\end{array}$ & $\begin{array}{l}33 \\
(41.8 \%)\end{array}$ & 2.84 & 1.255 \\
\hline $\begin{array}{l}\text { Continuous assessment regularly } \\
\text { conducted }\end{array}$ & $\begin{array}{l}30 \\
(38.0 \%)\end{array}$ & $\begin{array}{l}5 \\
(6.3 \%)\end{array}$ & $\begin{array}{l}44 \\
(55.7 \%)\end{array}$ & 2.87 & 1.362 \\
\hline Lecturers use self-evaluation & $\begin{array}{l}30 \\
(37.9 \%)\end{array}$ & $\begin{array}{l}14 \\
(17.7 \%)\end{array}$ & $\begin{array}{l}35 \\
(44.3 \%)\end{array}$ & 1.91 & 1.238 \\
\hline $\begin{array}{l}\text { Structure in place to support } \\
\text { internal assessment and records }\end{array}$ & $\begin{array}{l}49 \\
(63.0 \%)\end{array}$ & 17 & $\begin{array}{l}13 \\
(16.5 \%)\end{array}$ & 2.00 & 1.320 \\
\hline $\begin{array}{l}\text { There is a functional academic } \\
\text { committee }\end{array}$ & $\begin{array}{l}47 \\
(59.5 \%)\end{array}$ & $\begin{array}{l}3 \\
(3.8 \%)\end{array}$ & $\begin{array}{l}29 \\
(36.8 \%)\end{array}$ & 2.49 & 1.739 \\
\hline $\begin{array}{l}\text { Approved and disseminated quality } \\
\text { assurance policy }\end{array}$ & $\begin{array}{l}51 \\
(64.6 \%)\end{array}$ & $\begin{array}{l}2 \\
(2.5 \%)\end{array}$ & $\begin{array}{l}26 \\
(32.9 \%)\end{array}$ & 2.23 & 1.493 \\
\hline $\begin{array}{l}\text { Staff obtaining feedback from the } \\
\text { stakeholders }\end{array}$ & $\begin{array}{l}49 \\
(62.0 \%)\end{array}$ & $\begin{array}{l}2 \\
(2.5 \%)\end{array}$ & $\begin{array}{l}28 \\
(35.4 \%)\end{array}$ & 2.43 & 1.317 \\
\hline $\begin{array}{l}\text { College undertakes stakeholders' } \\
\text { surveys }\end{array}$ & $\begin{array}{l}60 \\
(76.0 \%)\end{array}$ & $\begin{array}{l}2 \\
(2.5 \%)\end{array}$ & $\begin{array}{l}17 \\
(21.8 \%)\end{array}$ & 1.94 & 1.530 \\
\hline $\begin{array}{l}\text { Obtain Feedback to improve the } \\
\text { quality }\end{array}$ & $\begin{array}{l}64 \\
(81.0 \%)\end{array}$ & $\begin{array}{l}0 \\
(0.0 \%)\end{array}$ & $\begin{array}{l}15 \\
(19.0 \%)\end{array}$ & 1.65 & 1.209 \\
\hline $\begin{array}{l}\text { Student assessment procedures are } \\
\text { clear }\end{array}$ & $\begin{array}{l}39 \\
(47.1 \%)\end{array}$ & $\begin{array}{l}3 \\
(3.8 \%)\end{array}$ & $\begin{array}{l}38 \\
(48.1 \%)\end{array}$ & 2.99 & 1.199 \\
\hline $\begin{array}{l}\text { There are mechanisms for } \\
\text { monitoring and evaluation }\end{array}$ & $\begin{array}{l}51 \\
(65.2 \%)\end{array}$ & $\begin{array}{l}2 \\
(2.5 \%)\end{array}$ & $\begin{array}{l}26 \\
33.0 \%)\end{array}$ & 2.75 & 1.126 \\
\hline $\begin{array}{l}\text { Heads of department share } \\
\text { information on quality }\end{array}$ & $\begin{array}{l}31 \\
(39.2 \%)\end{array}$ & $\begin{array}{l}23 \\
(29.1 \%)\end{array}$ & $\begin{array}{l}25 \\
(31.7 \%)\end{array}$ & 2.70 & 1.275 \\
\hline $\begin{array}{lll}\text { Students } & \text { evaluate } & \text { lecturers' } \\
\text { teaching } & & \end{array}$ & $\begin{array}{l}44 \\
(54.5 \%)\end{array}$ & $\begin{array}{l}2 \\
(3.8 \%)\end{array}$ & $\begin{array}{l}33 \\
(41.8 \%)\end{array}$ & 2.57 & 1.308 \\
\hline Programs are reviewed regularly & $\begin{array}{l}47 \\
(59.4 \%)\end{array}$ & $\begin{array}{l}6 \\
(7.6 \% 0)\end{array}$ & $\begin{array}{l}26 \\
(32.9 \%)\end{array}$ & 2.51 & 1.300 \\
\hline
\end{tabular}

The results in Table 6 indicate that $44 \%$ of the respondents agreed that there was regular staff appraisal with a mean response rate of 2.94. However, there were respondents who disagreed (33\%) with the statement. This could mean that some lecturers are not regularly appraised. This may affect the quality of their performance as well as that of the teacher trainees. On the issue of whether internal examinations were regularly administered to the teacher trainees in order to improve their performance, $37 \%$ of the respondents agreed with that 
statement. However, $25 \%$ of the lecturer disagreed with that statement. This implied that the staff members were not equally keen in the manner in which examinations are handled in the colleges. This may not augur well with ensuring the quality of the products from the colleges.

The results in Table 6 also show that $56 \%$ of the respondents agreed that continuous assessment was used during the training of the students with a mean response rate of 2.87. However, a significant number of lecturers disagreed (30\%) with the same statement; and this could imply that some colleges or departments do not use continuous assessment during training.

The results in Table 6 further reveal that most of the respondents strongly disagreed (52\%) that there are functional academic committees in place at the college with a mean response rate of 2.49 . However, some few lecturers (13\%) agreed that their colleges had functional academic committees. This could imply that the committees that are meant to guarantee quality in the colleges are not vibrant in ensuring quality in their respective institutions.

During the interviews, different respondents expressed different opinions concerning quality assurance in their colleges. One Principal observed that:

For me as a Principal, I am the chief quality controller in this college. I chair the academic committee, and I am responsible for ensuring the vibrancy of its operation. However, the academic committee sometimes fails to guarantee quality due to several factors including the poor attitudes of both staff and students. Nevertheless, we continue to guide both the staff and students to ensure that we produce quality work.

Another interviewee, a Registrar in one of the colleges said that:

As a college, we take the issue of quality seriously. We encourage our staff to follow the timetables, honor timelines, and give regular assessments and motivate students in the course of teaching. All these are geared towards quality assurance. While a few staff members may be uncommitted to these ideals, the majority of them appear to do a good job. Overall, the quality of our products is not so bad although, there is room for improvement.

The interview results indicated that the managers of the colleges are aware of the challenges they have in guaranteeing quality. They also recognized that the prevailing quality assurance systems they use are weak and need continuous improvement.

During the interviews held with the Ministry of Education and Sports' officials, the different interviewees expressed diverse opinions about quality and quality assurance in the NTCs. One of the officials remarked that:

The issue of quality and quality assurance in the NTCs is critical. With the ever-changing world and changing demands and lifestyles, program 
reviews should take precedence in any higher education institution. This is because there are many things that were taught ten years ago, but they have become obsolete now. Unfortunately, our lecturers in the NTCs do not seem to take programs evaluation and reviews seriously. Most often, they take several years before programs are reviewed; this impact negatively on the quality of the products from the NTCs.

The results indicated that both the local managers in the NTCs and the officials at the Ministry's headquarters recognize the challenges that are associated with ensuring quality in the NTCs; and the need for continuous improvement in quality assurance.

\section{Verification of Research Hypotheses}

The study aimed at verifying four research hypotheses, namely: $\mathrm{H}_{1}=$ Planning has a statistically significant influence on quality assurance; $\mathrm{H}_{2}=$ Organizing has a statistically significant influence on quality assurance; $\mathrm{H}_{3}=$ Controlling has a statistically significant influence on quality assurance, and $\mathrm{H}_{4}=$ Directing has a statistically significant influence on quality assurance. To verify these hypotheses, first, the hypotheses were converted into their null form. Secondly, the researcher generated indices for each of the variables, namely: planning (plan), organizing (org), controlling (cont) and directing (direct) as well as quality assurance (qa) using data obtained from the questionnaire. Thereafter, the hypotheses were tested with the use of the multiple regression techniques. The results of the tests of the null hypotheses are presented in Tables 7 (a), (b) and (c).

Table 7(a): Regression Model Summary

\begin{tabular}{|c|c|c|c|c|c|c|c|c|c|}
\hline \multirow[b]{2}{*}{ Model } & \multirow[b]{2}{*}{$\mathrm{R}$} & \multirow[b]{2}{*}{$\begin{array}{c}\mathrm{R} \\
\text { Square }\end{array}$} & \multirow[b]{2}{*}{$\begin{array}{c}\text { Adjusted R } \\
\text { Square }\end{array}$} & \multirow{2}{*}{$\begin{array}{l}\text { Std. Error } \\
\text { of the } \\
\text { Estimate }\end{array}$} & \multicolumn{5}{|c|}{ Change Statistics } \\
\hline & & & & & $\begin{array}{l}\text { R Square } \\
\text { Change }\end{array}$ & $\begin{array}{c}\mathrm{F} \\
\text { Change }\end{array}$ & df1 & df2 & $\begin{array}{c}\text { Sig. F } \\
\text { Change }\end{array}$ \\
\hline 1 & .591 。 & .349 & .314 & .36242 & 349 & 9.907 & 4 & 74 & .000 \\
\hline
\end{tabular}

a. Predictors: (Constant), Controlling, Planning, Organizing and Directing

b. Dependent Variable: Quality Assurance

The results in Table $7(\mathrm{a})$ show that the correlation coefficient between management and quality assurance is positive with an $R$ value of 0.591 and $R$ squared of 0.349 . These results suggest that a unit change in management leads to a $0.349(34.9 \%)$ change in quality assurance, other factors held constant. The observed significance $(\mathrm{p})$ value of 0.000 is lower than the critical significance value of 0.05 . This implies that management has a significant influence on quality assurance in the NTCs, other factors held constant. However, to determine whether the overall regression model is a good fit for the data, the researcher proceeded to perform the $\mathrm{F}$ ratio test which results are presented in Table 7(b). 
Table 7(b): ANOVA Table

\begin{tabular}{ll|l|l|l|l|l}
\hline Model & \multicolumn{1}{|c|}{$\begin{array}{c}\text { Sum of } \\
\text { Squares }\end{array}$} & df & $\begin{array}{c}\text { Mean } \\
\text { Square }\end{array}$ & F & Sig. \\
\hline 1 & Regression & 5.205 & 4 & 1.301 & 9.907 & $.000^{\mathrm{b}}$ \\
Residual & 9.720 & 74 & .131 & & \\
Total & 14.925 & 78 & & & \\
\hline
\end{tabular}

a. Dependent Variable: Qa

c. Predictors: (Constant), plan, org, cont, direct)

The results in the ANOVA table above $(\mathrm{F}(1.301)=9.907, \mathrm{p}<.05)$ show that the independent variable (management) significantly predict the dependent variable (quality assurance); that is, the regression model is a good fit of the data. Finally, to test for the influence of each independent variable on quality assurance, the multiple regression analysis was carried out. The results are presented in Table 7(c).

Table 7(c): Multiple regulation results for influence of management on quality assurance

\begin{tabular}{|c|c|c|c|c|c|c|c|c|}
\hline & \multirow[b]{2}{*}{ Model } & \multicolumn{3}{|c|}{ Unstandardized Standardized } & \multirow[b]{2}{*}{$\mathrm{T}$} & \multirow[b]{2}{*}{ Sig. } & \multicolumn{2}{|c|}{$\begin{array}{l}95.0 \% \text { Confidence } \\
\text { Interval for B }\end{array}$} \\
\hline & & B & $\begin{array}{l}\text { Std. } \\
\text { Error }\end{array}$ & $\begin{array}{c}\text { Coefficients } \\
\text { Beta }\end{array}$ & & & $\begin{array}{l}\text { Lower } \\
\text { Bound }\end{array}$ & $\begin{array}{l}\text { Upper } \\
\text { Bound }\end{array}$ \\
\hline 1 & $\begin{array}{l}\text { (Constant) } \\
\text { Planning }\end{array}$ & $\begin{array}{l}1.832 \\
.254\end{array}$ & $\begin{array}{l}.609 \\
.085\end{array}$ & .287 & $\begin{array}{l}3.008 \\
2.977\end{array}$ & .004 & $\begin{array}{l}.618 \\
.084\end{array}$ & $\begin{array}{l}3.045 \\
.425\end{array}$ \\
\hline & Organizing & -.099 & .067 & -.146 & 1.471 & .146 & -.233 & .035 \\
\hline & Controlling & -198 & .082 & -.238 & 2.414 & .018 & -.362 & -.035 \\
\hline & Directing & .461 & .113 & .388 & 4.081 & .000 & .236 & .686 \\
\hline
\end{tabular}

a. Dependent Variable: Quality assurance

The multiple regression results in Table 7(c) show that planning, controlling and directing have $p$-values of $0.004,0.018$, and 0.000 respectively which are less than the critical value of $p=.05$. These imply that planning, controlling and directing have statistically significant influence on quality assurance in NTCs. Therefore, the null hypotheses associated with these three variables (planning, controlling 
and directing) were rejected and their research hypotheses upheld. However, the results in the table also show that organizing had a p-value of 0.146 which is more than the critical value of $p=.05$ This implies that organizing has no statistically significant influence on quality assurance in NTCs. Therefore, the null hypothesis that "organizing has no statistically significant influence on quality assurance" was accepted and the research hypothesis rejected.

\section{Discussion of Findings}

In this study, the researchers aimed at achieving four specific objectives. First, the study was intended to establish the influence of planning on quality assurance in NTCs. Study findings revealed that both planning and quality assurance were weak in the colleges. However, the study also revealed that planning has a statistically significant influence on quality assurance ( $p$ $=.004<.005)$. The finding that planning is weak in the colleges is in agreement with the work of a number of other scholars who have generally studied planning in higher education institutions. For instance, Musaazi (2006) alludes to the fact that weak planning in many educational institutions arises out of weak implementation of both strategic and tactical plans. In fact, both strategic and operational plans of some of the colleges lacked focus on critical issues with regard to the management of quality in the institutions. In a scenario where weak planning occurs, it can negatively affect the institutional utilization of resources since effective planning, according to Ajeyalemi (2013)), is essential for controlling the use of human and material resources of an institution. But according to Azikuru, Onen and Ezati (2016) and Becket and Brookes (2008), for planning to enable the organisation to achieve its goal - say to ensure quality outputs - the process of planning needs to be more integrated and wellcoordinated. Such is the lesson administrators in NTCs in Uganda can learn.

The second finding that there was a weak quality assurance in the colleges is also in agreement with the works of scholars such as Rana (2009), and Herman (2000). According to Rana (2009), higher education institutions in Pakistan for instance, have weak quality assurance systems. Rana attributes this to a weak quality assurance framework adopted by the institutions. This is more or less inconsonant with the findings of this study where the qualitative results indicated that NTCs in Uganda have weak quality assurance frameworks. This finding is also in tandem with the work of Herman (2000) who investigated the development and management of quality assurance in higher education systems and institutions in Asia and the Pacific and discovered that several higher education institutions in Asia have weak institutional quality assurance mechanisms that make it difficult for them to guarantee the quality of their products and processes. This is not any different with the findings of Ngware, Ciera, Musyoka and Oketch (2015) who reported that "the average performance in quality education of African countries appears much poorer than elsewhere in the world. ... One way of improving the quality of education is through quality teaching" (p.1). However, you can hardly improve teaching without effective management of the quality assurance processes of an educational institution. This is yet another lesson that the managers of NTCs in Uganda can learn. 
The third and last important finding under objective one had to do with the influence of planning on quality assurance in NTCs. The finding that planning has a statistically significant influence on quality assurance is also in consonant with the work of a few other scholars. For instance, Ajeyalemi (2013) indicates that planning generally has influence on quality assurance in institutions of higher education; and in particular, he reveals that planning guarantees quality assurance because it enables institutional goals to be set prior to institutional operations. This view is also in congruence with that of Azikuru (2017) who argues that planning is central in guaranteeing not only the quality of teaching but the entire output of the higher education system.

Under objective two, two main findings were made. The first finding was that organizing as a management function was also weak in NTCs. Secondly, the study also established that organizing has a statistically weak influence on quality assurance in NTCs ( $\mathrm{p}$-value $=0.146>0.05$ ). The finding that organizing in NTCs is weak is also in agreement with the work of other scholars. For instance, Lawler, Mohrman, and Ledford (1992) discovered that organizations that are effectively organized in terms structure and work roles tend to have a clear span of control - thereby enhancing individual and teamwork.

Under objective three, two main findings were made. First, the study established that the control function of management in the NTCs was not very effective. Secondly, the study also discovered that control has a statistically significant influence on quality assurance ( $\mathrm{p}$-value $=0.018<0.05)$. These findings were also in agreement with the findings of a few other scholars. For instance, Sanyal (2013) indicated that among the nine academic assessment control factors, five factors appeared to influence quality assurance more than others. These include academic standards of students, teaching standards, student assessment, and utilization of coursework and test results. The other factors indicated minimal influential as far as assuring quality is concerned. These include research and project work. It is important to note that the two control factors that were regarded as having less influence on assurance quality are aspects that have been neglected in higher education especially in NTCs in Uganda. Moreover, these are an important aspect of preparing a teacher to always search for knowledge (Akiba, LeTendre \& Scribner, 2015). The staff control factor that respondents indicated as being instrumental in assuring quality was carrying out performance appraisals. Unfortunately, in the study, it was discovered that performance appraisal takes place only once a year in the NTCs. This discourages employees' work effort - thereby affecting the assurance of quality in the institutions.

Finally, under objective four, two main findings were also made. First, the study established that the directing function of management in the NTCs was ineffective. Secondly, the study also discovered that directing has a significant influence on quality assurance $(p=0.000<0.05)$. These findings were also in consonant with the work of different scholars. Mande, Nambatya, and Nsereko (2015) for instance, indicated that directing was a pertinent aspect of quality assurance in an institution. He explained that a manager's job does not only 
include employee management but also inspiring employees to work better for their personal gain, as well as the gain of the organization. But according to Adair (2005), directing can be explained in terms of three overlapping and interdependent circle task, team and individual which form the boundaries of what a leader must do to be effective, one is to be seen and best seen in action. The researchers reinforce the subscription of Jeremy that a leader has to define the task, plans for the best alternatives engaging others in an open minded, positive and creative way. Has to get the staff informed and motivated. Encourage them to work together, promote teamwork. The leader should develop a range of attributes such as demonstrating good work habits; understanding and evaluating the staff's work, handling pressure, dearly demonstrating the values and aims that one holds dear, encourage initiatives and enthusiasm providing regular considered feedback and listening and learning. Decisiveness, vision, understanding, and confidence contribute to the good working environment.

\section{Conclusion}

Based on the findings of the study, the researchers concluded that management indeed significantly influences the assurance of quality in NTCs in Uganda, other factors notwithstanding. Therefore, if NTCs are to ensure the production of quality teacher trainees, then their managers must undertake periodic audits and reviews of their operations in order to detect any anomalies regarding quality in their institutions. Besides, the managers must apply the principles of total quality management in order to engage all relevant stakeholders such as students and employees in managing quality at the institutions. Finally, the managers of NTCs are recommended to benchmark and adopt best practices of assuring quality from other institutions of higher education

\section{References}

Adair, J. (2010). Strategic leadership: How to think and plan strategically and provide direction. London: Kogan Page.

Adupa, C. B, \& Mulindwa, D.K. (Eds.) (1998). Institute of Teacher Education: Origins and developments. Kampala: ITEK.

Akiba, M., LeTendre, G. K., \& Scribner, J. P. (2015). Teacher quality, opportunity gap, and national achievement in 46 Countries. Education $\mathcal{E}$ Educational Research, 9 (224). Doi: https://doi.org/10.3102/0013189X07308739.

Ajeyalemi, D. (2013). The issues of quality and quantity in Nigeria's teacher education system.

Azikuru, L. M. E. (2017). Management and the quality of teaching in public universities in Uganda. Unpublished Doctoral Dissertation submitted to Makerere University, Uganda.

Azikuru, L. M. E., Onen, D. \& Ezati, B.A. (2016). The influence of planning on the quality of teaching in public universities. International Journal of Education and Research, 4(12), pp. 121-132.

Becket, N. and Brookes, M. (2008). "Quality management practices in higher educationwhat quality are we actually enhancing". Oxford Brookes University, Oxford. Journal of Hospitability, Leisure, Sport and Tourism Education. Vol: 7 No: 1. Doi: https:// doi.org/10.3794/johlste.71.174

Deming, W.E. (1986). Out of Crisis. MIT Center for Advanced Engineering Study, Cambridge, MA. 
Hashmi, K. (2017). Introduction to Implementation of Total Quality Management (TQM). An Article down loaded on 4/12/2017 from https://www.isixsigma.com/methodology/total-quality-managementtqm/introduction-and-implementation-total-quality-management-tqm/

Harman, G. \& Meek, V. L. (2000). Harman, G. and L. V. Meek (2000). Repositioning Quality Assurance and Accreditation in Australian Higher Education. Canberra, University of New England: 108.

Harman, G. (2000). Quality assurance in Higher Education, Bangkok: Ministry of University Affairs and UNESCO, PROAP. P.1.

Harvey, L. \& Green, D. (1993). Defining Quality in Assessment and Evaluation in Higher Education, 18 (1).

Harvey, L. (2005). A history and critique of quality evaluation in the UK in QA in E 13 (4).

Lawler, E. E., Mohrman, S. A., \& Ledford, G. E. (1992). Employee involvement and total quality management: Practices and results in Fortune 1000 companies. San Francisco: Jossey-Bass.

Mande, W. M., Nambatya, A. K., \& Nsereko, N. D. (2015). Contribution of middle management to enhancement of quality education in Ugandan Universities. Nkumba Business Journal, 14.

Manivannan, S. (2016). Chapter-24 Assuring Quality in Nursing Colleges. Nursing Education \& Quality Assurance in Nursing Colleges, 249-252. doi:10.5005/jp/books/12876_25

Ministry of Education and Sports. (2015). Inspection report on national teacher's colleges. Kampala: Author.

Mullins, L. (2010). Management and Organizational Behaviour. London: Prentice Hall.

Musaazi, J. (2006). Educational Planning- Principles, Tools and Applications. Kampala: Makerere University Printery.

Ngware, M. W., Ciera, J., Musyoka, P.K \& Oketch, M. (2015). Quality of teaching mathematics and learning achievement gains: evidence from primary schools in Kenya. Educ Stud Math, Doi: https://doi.org/10.1007/s10649-015-9594-2

Rana, S. (2009). Quality management in higher education - a perspective. Proceedings $2^{\text {nd }}$ CBRC, Lahore, Pakistan.

Rodrigues, C.A. (2001). Fayol's 14 principles of management then and now: A framework for managing today's organizations effectively. Management Decision, Vol. 39 Issue: 10, pp. 880-889. Doi: https://doi.org/10.1108/eum0000000006527

Sanyal, B, C. (2013). Quality assurance of teacher education in Africa. Addis Ababa, UNESCO: International Institute for Capacity Building in Africa.

Singh, R.K. (2011) "Analysing the interaction of factors for success of total quality management in SMEs", Asian Journal on Quality, 12 (1), 6 - 19. Doi: https:// doi.org/10.1108/15982681111140516

Smith, J.L. (2011). Management: The lasting legacy of the modern quality giants. Down loaded on 10/10/2017 from https://www.qualitymag.com/article.

UNESCO. (2017). Quality Educators for All. Downloaded on 6 th $^{\text {th }}$ December 2017 from www.unescobkk.org/education/news/.../no-education-system-is-better-thanits-teacher. 